\title{
Passion Fruit (Passiflora spp.) species as sources of resistance to soil phytopathogens Fusarium solani and Fusarium oxysporum f. sp. passiflorae complex
}

\author{
Juliana Avelar de Carvalho' ${ }^{1}$ Jeferson Gonçalves de Jesus², Kelly Lana Araujo ${ }^{3}$, \\ Milson Evaldo Serafim ${ }^{4}$, Thiago Alexandre Santana Gilio $^{3}$, Leonarda Grillo Neves ${ }^{3}$. \\ Abstract - The stem rot and fusarium vascular wilt are among the main factors the most limiting the \\ passion fruit cultivation in the State of Mato Grosso. This study aimed to evaluate the resistance / \\ susceptibility of the genus Passiflora species to soil pathogens from different biomes of Mato Grosso \\ (Cerrado, Pantanal and Amazon). The part I evaluated the response of $P$. edulis Sims, $P$. foetida, $P$. \\ nitida and P. quadrangularis on eight isolates of $F$. solani. In part II was evaluated the genotypes $P$. \\ edulis Sims, P. mucronata, P. foetida, P. nitida and P. morifolia on three isolates of $F$. oxysporum f. sp. \\ passiflorae. The experimental design was randomized blocks in factorial arrangement (genotypes $\mathrm{x}$ \\ isolates). The statistical analysis used for both steps were the variance analyses by $\mathrm{F}$ test and grouping \\ of averages of genotypes by Scott-Knott test $(P \leq 0.05)$. Among the isolates of $F$. solani was found that \\ isolates FS8A and FS3P are more aggressive, indicating genetic variability among isolates. The most \\ resistant genotypes to the pathogen were $P$. nitida and $P$. foetida. Among the isolates of $F$. oxysporum \\ f. sp. passiflorae there was no significant difference in aggressive levels, and the P. mucronata and $P$. \\ nitida species are more resistant to Fusarium. Thus genotypes $P$. nitida, foetida and P. mucronata can \\ be indicated as a resistance source to improvement of commercial passionfruit programs. \\ Index terms: Collar rot, fusariosis disease, Genetic breeding, Passiflora ssp.

\section{Diferentes espécies de maracujá como fonte de resistência aos patógenos de solo do complexo fusarium solani and fusarium}

$$
\text { oxysporum f. Sp. passiflorae }
$$

Corresponding author: julianaavelar.carvalho@hotmail. com

Received: March 09, 2020 Accepted: October 14, 2020

Copyright: All the contents of this journal, except where otherwise noted, is licensed under a Creative Commons Attribution License.

Resumo - A podridão do colo e a fusariose causadas, respectivamente, pelos fungos de solo Fusarium solani e Fusarium oxysporum f. sp. passiflorae, estão entre os principais fatores que limitam o cultivo do maracujazeiro no Brasil. O presente trabalho teve como objetivo avaliar a resistência/ suscetibilidade de espécies do gênero Passiflora aos patógenos de solo $F$. solani e $F$. oxysporum $\mathrm{f}$. sp. passiflorae de diferentes biomas do Mato Grosso (Cerrado, Pantanal e Amazônia). Na Etapa I, avaliou a reação de $P$. edulis Sims, $P$. foetida, $P$. nitida e $P$. quadrangulares a oito isolados de $F$. solani. Na Etapa II, foram avaliados os genótipos $P$. edulis Sims, $P$. mucronata, $P$. foetida, $P$. nitida e P. morifolia a três isolados de F. oxysporum f. sp. passiflorae. O delineamento experimental foi em blocos casualizados em arranjo fatorial (genótipos x Isolados). As análises estatísticas utilizadas para ambas as etapas foram análise de variância pelo teste $\mathrm{F}$ e agrupamento de médias dos genótipos pelo teste de Scotmas t-Knott $(\mathrm{P} \leq 0,05)$. Para tal, foram utilizados os recursos computacionais do programa Genes. Entre os isolados de F. solani avaliados, foi constatada maior agressividade dos isolados FS8A e FS3P, indicando variabilidade genética entre os isolados. Os genótipos mais resistentes ao patógeno foram $P$. nitida e $P$. foetida. Dentre os isolados de $F$. oxysporum f. sp. passiflorae, não foi observado diferença significativa ao nível de agressividade, sendo as espécies $P$. mucronata e $P$. nitida mais resistentes à Fusariose. Assim os genótipos $P$. nitida, $P$. foetida e $P$. mucronata podem ser indicados como fonte de resistência para programas de melhoramento do maracujazeiro comercial. Termos para indexação: Murcha de Fusarium, Fusariose, Melhoramento genético e Passiflora ssp.

\footnotetext{
${ }^{\top}$ M.Sc., Master degree program in genetics and plant breeding, Universidade do Estado de Mato Grosso, Cáceres-MT, Brazil. E-mail: julianaavelar.carvalho@hotmail.com (ORCID: 0000-0002-4952-4169)

${ }^{2}$ Master student in genetics and plant breeding, Universidade do Estado de Mato Grosso, Cáceres-MT, Brazil. E-mail: jeferson_gjesus@ hotmail.com (ORCID: 0000-0002-1728-3129)

${ }^{3}$ Ph.D.., Professor, Master degree program in genetics and plant breeding, Universidade do Estado de Mato Grosso, Cáceres-MT, Brazil. E-mail: kellylana@unemat.br (ORCID: 0000-0003-4558-9480)

${ }^{4} \mathrm{Ph} . \mathrm{D}$. Professor at Instituto Federal de Educação, Ciência e Tecnologia, Cáceres-MT, Brazil. E-mail: milson.serafim@cas.ifmt.edu.br ${ }^{\text {(ORCID: }}$ 0000-0002-2400-7712)

${ }^{5} \mathrm{Ph} . \mathrm{D} . .$, Professor, Master degree program in genetics and plant breeding, Universidade do Estado de Mato Grosso, Cáceres, MT, Brazil. Email: thiago gilio@hotmail.com(ORCID: 0000-0003-4078-5407)

${ }^{6} \mathrm{Ph} . \mathrm{D} . .$, Professor, Master degree program in genetics and plant breeding, Universidade do Estado de Mato Grosso, Cáceres-MT, Brazil. E-mail:leonardaneves@unemat.br
} 


\section{Introduction}

Passion fruit is generally associated with species of the Passifloraceae family, particularly those belonging to the genus Passiflora There are more than 400 species in the genus Passiflora, which, about these species Passiflora edulis is the most widely cultivated,and it belongs to the Theoideae suborder, Passifloraceae family, and Passiflora L. genus. Passion fruit has really high contents of nutrition, including sugar, fat, protein, vitamins and mineral elements (Bernacci et al., 2015; MUNHOZ et al., 2018). Brazil also is considered an important center of genetic diversity of the genus Passiflora, with approximately 141 known native species with wide use in the food, drug and ornamental areas (BERNACCI et al., 2014), furthermore it is known as the largest world producer of passion fruit (FAO 2019).

In the last year in the production of sour passion fruit is decreasing significatively (IBGE 2017). Between the causes of production decreasing the disease problems causes by viruses and soil pathogens are by far the most important problems (Silva et al, 2017).

Among the diseases important to passion fruit in Brazil, collar rot, caused by the fungus Fusarium solani, and fusariosis, caused by Fusarium oxysporum f. sp. passiflorae, are highlighted (SILVA et al., 2013) due the high susceptibility of all the varieties from the specie Passiflora edulis Sims. These soil fungi have caused great damage to the passion fruit crop by causing plant death and reduced plant life (PREISIGKE et al., 2015a). In order to control collar rot and fusariosis, resistant wild species are used as rootstocks for sour passion fruit and/or for obtaining interspecific hybrids (FLORES et al., 2012; SANTOS et al., 2016). However, the most efficient form of control of this disease is the use of resistant cultivars. there are reports of resistance in wild species PREISIGKE et al., 2015a; MAROSTEGA et al., 2019).
In this context, the present work aimed to evaluate the interaction of isolates of $F$. solani and $F$. oxysporum f. sp. passiflorae, from the biomes of Mato Grosso, with species of $P$. edulis Sims, $P$. foetida Linn., P. nitida Kunth., P. quadrangularis Linn., P. morifolia Mast. and $P$. mucronata Lam., from the UNEMAT's work collection, to improve the breeding program of the species in the state.

\section{Materials and Methods}

The experiments were conducted in a greenhouse located in the experimental field of the Laboratory of Genetics and Plant Breeding of the State University of Mato Grosso - UNEMAT, Cáceres Campus. The municipality of Cáceres is located in the southwest of Mato Grosso, integrating the upper Pantanal microregion with the central-south region of Mato Grosso. The city of Cáceres is located at $16^{\circ} 04^{\prime} 14^{\prime \prime} \mathrm{S}$ latitude and $57^{\circ} 40^{\prime} 44^{\prime \prime}$ W longitude, with an altitude of 118 meters, according to (IBGE, 2014a).

The experiments were conducted in two steps, as described below.

Step I: Evaluation of the genetic resistance of Passiflora species to the fungus $F$. solani:

It consisted in evaluating the resistance of four species of Passiflora to eight different isolates of $F$. solani, being three from the Amazonian biome, three from Cerrado and two from Pantanal, according to Table 1. All the isolates from the complex $F$. solani were obtained from plants of $P$. edulis host. Furthermore, molecular characterization and the confirmation that each isolate belongs to $F$. solani complex were done by Marostega et al. (2019).

Table 1. Location and biomes of origin of the Fusarium solani isolates used in this study.

\begin{tabular}{|c|c|c|c|c|}
\hline \multirow{2}{*}{ Isolate } & \multirow{2}{*}{ Location } & \multirow{2}{*}{ Biome } & \multicolumn{2}{|c|}{ Geographic Coordinates } \\
\hline & & & Latitude & Longitude \\
\hline FS1A & São José do IV Marcos & Amazon & $15^{\circ} 36.4 ’ 51 ” S$ & $58^{\circ} 15.0 ’ 87^{\prime} \mathrm{W}$ \\
\hline FS16C & Campo Verde & Cerrado & $15^{\circ} 21^{\prime} 04.0 ” \mathrm{~S}$ & $54^{\circ} 45^{\prime} 18.8^{\prime \prime} \mathrm{W}$ \\
\hline FS5C & Tangará da Serra & Cerrado & $14^{\circ} 42^{\prime} 28.5^{\prime} \mathrm{S}$ & $57^{\circ} 27^{\prime} 26.1 ” \mathrm{~W}$ \\
\hline FS8A & São José do IV Marcos & Amazon & $15^{\circ} 37^{\prime} 13.72^{\prime} \mathrm{S}$ & $58^{\circ} 17^{\prime} 02.78^{\prime \prime} \mathrm{W}$ \\
\hline FS5P & Santo Antônio do Leverger & Pantanal & $16^{\circ} 07^{\prime} 36.7^{\prime \prime} \mathrm{S}$ & $55^{\circ} 51^{\prime} 32.4 ” \mathrm{~W}$ \\
\hline FS11A & Carlinda & Amazon & $9^{\circ} 57^{\prime} 23.57^{\prime \prime S}$ & $55^{\circ} 49^{\prime} 53.09^{\prime \prime} \mathrm{W}$ \\
\hline FS3P & Nossa Senhora do Livramento & Pantanal & $16^{\circ} 19^{\prime} 20.9^{\prime \prime} \mathrm{S}$ & $58^{\circ} 13^{\prime} 43.9^{\prime \prime} \mathrm{W}$ \\
\hline FS9C & Campo Verde & Cerrado & $15^{\circ} 44^{\prime} 36.3^{\prime \prime} \mathrm{S}$ & $55^{\circ} 25^{\prime} 33.3^{\prime \prime} \mathrm{W}$ \\
\hline
\end{tabular}


The four species of Passiflora were: P. edulis Sims, P. foetida, P. nitida and P. quadrangularis, previously identified as resistant to the fungus according to (Preisigke et al., 2015a). The production of cuttings was also evaluated.

The cuttings were planted in a 72-cell tray with Plantimax ${ }^{\circledR}$ substrate (Eucatex Mineral Ltda., PaulíniaSP) previously moistened, applying Biofert ${ }^{\circledR}$ foliar fertilizer three times a week. The experimental design was a randomized complete block design with 32 treatments in a $4 \times 8$ factorial scheme ( 4 genotypes and 8 isolates), three replicates and two plants per plot.

At 60 days after planting, the rooted cuttings were inoculated with the isolates of $F$. solani from monosporic culture.For the inoculum preparation, monosporic isolates, preserved in filter paper, was replicated in Petri dishes containing BDA and incubated in growing chamber (B.O.D.) at $24{ }^{\circ} \mathrm{C}$ and light period of $12 \mathrm{~h}$ during 7 days. Inoculation was performed as described by Fischer et al. (2003). A discus (5 mm diameter) of culture media containing profuse mycelium growth was retired from the Petri dishes and fixed with PVC plastic tape over a small injury in the plant stem, at a distance of $2 \mathrm{~cm}$ from the soil. The plastic tape was removed five days after inoculation (DAI). The same procedure was applied to the control treatment, but without the media culture discus containing fungus.

The reaction of the inoculated plants was evaluated from the 5th day after inoculation to the 67 th day or until the death of the plants. Five resistance characteristics were analyzed according to (PREISIGKE et al., 2015a), being: Number of plants in which the lesion has reached less than $50 \%$ of the plant circumference (NPL-50\%); Inoculation period until the lesion has reached more than $50 \%$ of the circumference of the injured stem of the plant (IPLR+50\%); Number of plants in which the lesion injured the marrow (NPLM); Area Under the Disease Progress Curve (AUDPC); Number of dead plants (NDP).

Lesions of the NPL- $50 \%$ and IPLR $+50 \%$ characteristics were determined throughout the day after the inoculation when the lesion has reached the respective measurements. NPLM was determined at the end of the experiment through a cross section in the middle of the lesion, and it was observed whether the lesion has reached the plant marrow. NDP was observed and recorded during the experiment.
In both characteristics, the lesions were measured every 2 days for length and width of the necrosis, with the aid of a pachymeter. For the AUDPC, the necrotic area was estimated through the area of the ellipse $\left(\pi^{*} \mathrm{~L}^{*} \mathrm{~W} / 4\right)$, where $\mathrm{L}$ is the length and $\mathrm{W}$ the width. The AUDPC was then calculated according to (SHANER and FINNEY, 1977); subsequently, the AUDPC was divided by the observations period (period of days between the beginning and the last measurement of the lesion) according to (FRY, 1977).

The genetic-statistical model used (considering genotypes and $F$. solani isolates as fixed effects) was: $\mathrm{Y}_{\mathrm{ijk}}$ $=\mathrm{m}+\mathrm{G}_{\mathrm{i}}+\mathrm{I}_{\mathrm{j}}+\mathrm{GI}_{\mathrm{ij}}+\mathrm{B}_{\mathrm{k}}+\mathrm{E}_{\mathrm{ij}, \mathrm{k}}$, where $\mathrm{G}_{\mathrm{i}}$ : effect of the ith genotype of Passiflora ( $\mathrm{i}=1,2, \ldots, 4)$; $\mathrm{I}$ : effect of the jth isolate of Fusarium solani $(\mathrm{j}=1,2, \ldots, 8)$; $\mathrm{GI}_{\mathrm{ij}}$ : effect of the interaction between the ith genotype and the jth isolate; $\mathrm{B}_{\mathrm{k}}$ : effect of kth block $(\mathrm{k}=1,2,3)$ and $\mathrm{E}_{\mathrm{ijk}}$ : random error. The NDP, NPLM and NPL-50\% data were transformed by the equation $\sqrt{\left(x_{i}+0.5\right)}$, where $x_{i}$ is the characteristic's value observed in plot $i$, and the AUDPC was transformed by logarithm and submitted to statistical analysis.

The statistical analyses used to evaluate the results were analysis of variance by $\mathrm{F}$ test and grouping of means of genotypes by Scott-Knott test $(\mathrm{P}<0.05)$. For that, the computational resources of the Genes program (Cruz, 2013) were used.

\section{Step II: Evaluation of the resistance of Passiflora species to the fungus $F$. oxysporum f. sp. passiflorae.}

Five genotypes of differentials species of Passiflora, P. edulis Sims, $P$. nitida, P. foetida, P. mucronata and $P$. morifolia, were evaluated in relation to three different isolates of F. oxysporum f. sp. passiflorae, each isolate coming from the Cerrado, Pantanal and Amazonian biomes, according to Table 2 . All the isolates F. oxysporum f. sp. passiflorae were obtained from plants of $P$. edulis host. Furthermore, molecular characterization and the confirmation that each isolate belongs to $\boldsymbol{F}$. oxysporum f. sp. passiflorae specie were done by Marostega et al. (2019).

Table 2. Location of collection of the Fusarium oxysporum f. sp. passiflorae isolates. Cáceres, 2015.

\begin{tabular}{|c|c|c|c|c|}
\hline \multirow{2}{*}{ Isolate } & \multirow{2}{*}{ Location } & \multirow{2}{*}{ Biome } & \multicolumn{2}{|c|}{ Geographic Coordinates } \\
\hline & & & Latitude & Longitude \\
\hline FO1C & Cáceres & Cerrado & $16^{\circ} 04^{\prime} 43.3^{\prime \prime} \mathrm{S}$ & $57^{\circ} 33^{\prime} 41.1 " \mathrm{~W}$ \\
\hline FO4A & São José dos IV Marcos & Amazon & $15^{\circ} 39.8^{\prime} 30^{\prime \prime} \mathrm{S}$ & $58^{\circ} 18.5^{\prime} 15^{\prime \prime} \mathrm{W}$ \\
\hline FO1P & Cáceres & Pantanal & $16^{\circ} 09^{\prime} 89^{\prime \prime} \mathrm{S}$ & $57^{\circ} 37^{\prime} 22.29^{\prime \prime} \mathrm{W}$ \\
\hline
\end{tabular}


The preparation of cuttings, planting and fertilization followed the same recommendations described in the first step. The experimental design was a randomized complete block design with 15 treatments in a $5 \times 3$ factorial scheme, that is, 5 genotypes and 3 isolates, with three replicates, the plot consisting of two plants.

The three isolates of F. oxysporum f. sp. passiflorae used as source of inoculum for the respective experiment were from monosporic culture. For inoculation of the fungus, the filter paper segments preserved in the Micoteca were transplanted into Petri dishes containing PDA (potato-dextrose-agar) culture medium. After the fungus was transplanted, the plates were maintained in BOD at $25^{\circ} \mathrm{C}$ with $12 \mathrm{~h}$ photoperiod for a period of 7 days. Following this incubation period, segments of colonies of fungi were withdrawn and observed, and their sporulation was confirmed via microscopy.

After the incubation period, $10 \mathrm{~mL}$ of distilled water were poured into Petri dishes containing the fungus colony, in order to obtain a spore suspension. The spore suspension was adjusted to a concentration of $1 \times 10^{6}$ spores per $\mathrm{mL}^{-1}$, with the aid of a Neubauer chamber. This spore solution was prepared minutes before inoculation.

For the inoculation, the cuttings were removed from the trays, the roots were washed in distilled water and injuries were made with the aid of scissors for the pathogen to enter. The inoculation occurred by submerging the roots of the cuttings in spore solution for a period of 24 hours. After this period, the solution was replaced by a nutrient solution recommended by (CLARK, 1975), which was changed every 4 days.

The reaction of plants inoculated with F. oxysporum f. sp. passiflorae was evaluated through two resistance characteristics, Mean Survival Time (MST), which is the time in days from inoculation to plant death, and Number of Live Plants (NLP), according to (PREISIGKE et al., 2015a). Once the plant died or at the end of the experiment, the pathogen was reisolated in both plants through Koch's postulate to confirm the presence of the pathogen in the plant.

The genetic-statistical model used, including genotypes and $F$. oxysporum $\mathrm{f}$. sp. passiflorae isolates as fixed effects, was: $\mathrm{Y}_{\mathrm{ijk}}=\mathrm{m}+\mathrm{G}_{\mathrm{i}}+\mathrm{I}_{\mathrm{j}}+\mathrm{GI}_{\mathrm{ij}}+\mathrm{B}_{\mathrm{k}}+\mathrm{E}_{\mathrm{ij} \mathrm{k}}$, where $\mathrm{G}_{\mathrm{i}}$ : effect of the ith genotype of Passiflora $(\mathrm{i}=1,2, \ldots, 5)$; $\mathrm{I}_{\mathrm{j}}$ : effect of the jth isolate of $F$. oxysporum $\mathrm{f}$. sp. passiflorae $(j=1,2,3)$; GI $I_{i j}$ effect of the interaction between the ith genotype and the jth isolate; $\mathrm{B}_{\mathrm{k}}$ : effect of kth block $(\mathrm{k}=$ $1,2,3)$ and $\mathrm{E}_{\mathrm{ijk}}$ : random error.

The NLP data were transformed by $\sqrt{\left(x_{i}+0.5\right)}$, where $x_{i}$ is the characteristic's value observed in plot $\mathrm{i}$. The MST data have not undergone any transformation.
The statistical analyses used to evaluate the results were analysis of variance and grouping of means of genotypes by Scott-Knott test $(\mathrm{P}<0.05)$. For that, the computational resources of the Genes program (CRUZ, 2013) were used.

\section{Results and Discussion}

\section{Genetic resistance of Passiflora species to Fusarium solani complex}

The summary of the analysis of variance of the resistance characteristics evaluated, AUDPC, NDP, NPLM, NPL- $50 \%$ and IPLR $+50 \%$, is presented in table 3. Significant differences were found between the genotypes of for different species of Passiflora spp. These resistant differences were observed with the resistance characteristics AUDPC, NPLM and NPL-50\%.Also differences of aggressiveness were observed between isolates with the resistance traits NDP and IPLR $+50 \%$ (Table 3).

The interaction between passion fruit species and F. solani isolates for the variables NDP and IPLR $+50 \%$ where significatively $(\mathrm{P} \leq 0.05)$. The $\mathrm{F}$ test showed significance at $1 \%$ probability level between genotypes for the variables AUDPC and NPLM, and at 5\% probability level for the characteristic NPL-50\%. Among the isolates, the variables NDP and IPLR $+50 \%$ were significant at $1 \%$ and $5 \%$, respectively.

About the resistance characteristic IPLR $+50 \%$, there was a significant difference for the isolates FS5C, FS8A e FS3P $(\mathrm{P} \leq 0.05)$, in which, for the isolate FS5C the species $P$. edulis, $P$. foetida and $P$. nitida were considered resistant when compared with $P$. quadrangularis, however for the isolate FS3P the passion fruit specie P. edulis had the lowest period until the lesion has reached more than $50 \%$ of the plant stem circunference, indicative of susceptibility of $P$. edulis when compered with the other three species. Comparing the reaction of the isolate FS8A in the four species of Passiflora sp., P. foetida e P. nitida had the highest period until the lesion has reached more than $50 \%$ of the plant stem circunference indicative of resistance to of these species to this isolate from the $F$. solani complex (Table 4). 
Table 3. Variance analysis summary for five characteristics related to the interaction of four species of Passiflora and eight Fusarium solani isolates, with variation sources and their respective, evaluated in four Passiflora genotypes in relation to eight Fusarium solani isolates.

\begin{tabular}{|c|c|c|c|c|c|c|}
\hline \multirow{2}{*}{ SV } & \multicolumn{6}{|c|}{ Mean Squares } \\
\hline & DF & AUDPC & NDP & NPLM & NPL-50\% & IPLR+50 \\
\hline BLOCKS & 2 & 2.19 & 0.09 & 0.22 & 0.09 & 113.54 \\
\hline GENOTYPES (G) & 3 & $0.33^{* *}$ & $1.18^{\mathrm{ns}}$ & $0.26^{* *}$ & $0.12^{*}$ & $219.15^{\text {ns }}$ \\
\hline ISOLATES (I) & 7 & $0.14^{\mathrm{ns}}$ & $0.06^{* *}$ & $0.03^{\mathrm{ns}}$ & $0.04^{\mathrm{ns}}$ & $195.04^{*}$ \\
\hline GxI & 21 & $0.10^{\mathrm{ns}}$ & $0.15^{*}$ & $0.02^{\text {ns }}$ & $0.04^{\mathrm{ns}}$ & $153.09^{*}$ \\
\hline $\mathrm{G} / \mathrm{I}$ & 24 & - & $0.28^{* *}$ & - & - & $161.35^{*}$ \\
\hline G/FS1A & 3 & - & $0.11^{\text {ns }}$ & - & - & $19.89^{\text {ns }}$ \\
\hline G/FS16C & 3 & - & $0.22^{\mathrm{ns}}$ & - & - & $58.97^{\mathrm{ns}}$ \\
\hline G/FS5C & 3 & - & $0.47^{* *}$ & - & - & $306.00^{*}$ \\
\hline G/FS8A & 3 & - & $0.06^{\mathrm{ns}}$ & - & - & $233.11^{\text {ns }}$ \\
\hline G/FS5P & 3 & - & $0.22^{\mathrm{ns}}$ & - & - & $14.75^{\text {ns }}$ \\
\hline G/FS11A & 3 & - & $0.22^{\mathrm{ns}}$ & - & - & $45.86^{\mathrm{ns}}$ \\
\hline G/FS3P & 3 & - & $0.40^{* *}$ & - & - & $516.97^{*}$ \\
\hline G/FS9C & 3 & - & $0.52^{* *}$ & - & - & $95.22^{\mathrm{ns}}$ \\
\hline $\mathrm{I} / \mathrm{G}$ & 28 & - & $0.12^{\mathrm{ns}}$ & - & - & $163.57^{*}$ \\
\hline $\mathrm{I} / P$. edulis & 7 & - & $0.16^{\mathrm{ns}}$ & - & - & $304.56^{* *}$ \\
\hline $\mathrm{I} / P$. foetida & 7 & - & $0.16^{\mathrm{ns}}$ & - & - & $59.75^{\text {ns }}$ \\
\hline $\mathrm{I} / P$. nítida & 7 & - & $0.05^{\mathrm{ns}}$ & - & - & $21.85^{\text {ns }}$ \\
\hline $\mathrm{I} / P$. quadrangulares & 7 & - & $0.13^{\text {ns }}$ & - & - & $268.13^{* *}$ \\
\hline RESIDUE & 62 & 0.08 & 0.08 & 0.05 & 0.03 & 84.84 \\
\hline TOTAL & 95 & & & & & \\
\hline $\mathrm{CV}(\%)$ & & 16.96 & 28.06 & 15.75 & 12.4 & 15.07 \\
\hline
\end{tabular}

** and $*$ Significant at $1 \%$ and $5 \%$ probability by $\mathrm{F}$ test. ${ }^{\text {ns }}$ Not significant. Degrees of freedom (DF), mean squares and coefficients of variation (CV) for the characteristics AUDPC (area below the disease progression curve), NDP (number of dead plants), NPLM (number of plants in which the lesion injured the plant marrow), NPL-50\% (number of plants in which the lesion has reached less than $50 \%$ of the plant circumference) and IPLR $+50 \%$ (inoculation period until the lesion has reached more than $50 \%$ of the circumference of the injured stem of the plant)

Table 4. Average Inoculation period until the lesion has reached more than $50 \%$ of the plant stem circunference (IPLR+50\%) (Fusarium solani complex).

\begin{tabular}{lcccccccc}
\hline Genotypes of & \multicolumn{7}{c}{ Isolates } \\
\cline { 2 - 8 } Passiflora spp. & FS1A & FS16C & FS5C & FS8A & FS5P & FS11A & FS3P & FS9C \\
\hline P. edulis & $63 \mathrm{Aa}^{1}$ & $67 \mathrm{Aa}$ & $57 \mathrm{Aa}$ & $49 \mathrm{Bb}$ & $63 \mathrm{Aa}$ & $65 \mathrm{Aa}$ & $39 \mathrm{Bb}$ & $67 \mathrm{Aa}$ \\
P. foetida & $67 \mathrm{Aa}$ & $57 \mathrm{Aa}$ & $60 \mathrm{Aa}$ & $67 \mathrm{Aa}$ & $67 \mathrm{Aa}$ & $58 \mathrm{Aa}$ & $67 \mathrm{Aa}$ & $61 \mathrm{Aa}$ \\
P. nitida & $62 \mathrm{Aa}$ & $63 \mathrm{Aa}$ & $60 \mathrm{Aa}$ & $67 \mathrm{Aa}$ & $63 \mathrm{Aa}$ & $67 \mathrm{Aa}$ & $66 \mathrm{Aa}$ & $67 \mathrm{Aa}$ \\
P. quadrangularis & $66 \mathrm{Aa}$ & $66 \mathrm{Aa}$ & $39 \mathrm{Cb}$ & $55 \mathrm{Bb}$ & $67 \mathrm{Aa}$ & $63 \mathrm{Aa}$ & $54 \mathrm{Ba}$ & $55 \mathrm{Ba}$ \\
\hline
\end{tabular}

${ }^{1}$ Means followed by the same uppercase letters HORIZONTALLY and lowercase letters VERTICALLY constitute a statistically homogeneous group by Scott-Knott test at $5 \%$ probability level $(\mathrm{P}<0.05)$. 
Also in Table 4 , it is possible to obeserve a agressiveness variation among the eight isolates of $F$. solani complex. This variations was observed in P. edulis, were the isolates FS8A and FS3P reached more than 50\% of the plant stem circunference significantly faster then the others isolates of the $F$. solani complex. This agressivenees variantions was constated in P. quadrangularis, which the isolate $\mathrm{FS} 5 \mathrm{C}$ was considered the most agressive isolate.

The number of dead plants were lower in the species $P$. foetida and $P$. nitida when inoculated with the isolate. Also the species P. quadrangularis, P. foetida and P. nitida, had a lower number of dead plants for the isolates FS3P and FS9C, when compared with $P$. edulis. The significant difference between the species for the resistant trait NDP indicates lower mortality of genotypes from the species $P$. foetida, P. nitida and P. quadrangularis in reaction to the complex F. solani (Table 5). The lowest number of dead plants is an indicative of resistance between genotypes comparisons. This characteristics and others has been used by many authors to discriminated resistant genotypes from susceptible genotypes in different Passiflora spp. (Preisigke et al., 2015; Marostega et al., 2019)

Also the number of plants in which the lesion injured the plant marrow were lower for the specie $P$. nitida, while the number of plants in which the lesion has reached less than $50 \%$ of the plant circumference was lower in NPL-50\% for the specie P. quadrangulares. The area below the disease progress curve caused by the complex $F$. solani were lower in $P$. foetida. These three characteristics also indicated that $P$. foetida, $P$. nitida and $P$. quadrangulares are resistant to the complex $F$. solani when compared with P. edulis (Table 6).

Table 5. Average number of dead plants (NDP) of four passion fruit species inoculated with eight isolates from Fusarium solani complex.

\begin{tabular}{lcccccccc}
\hline Genotypes of & \multicolumn{7}{c}{ Isolates } \\
\cline { 2 - 8 } Passiflora .spp. & FS1A & FS16C & FS5C & FS8A & FS5P & FS11A & FS3P & FS9C \\
\hline P. edulis & $1.00 \mathrm{a}^{1}$ & $1.33 \mathrm{a}$ & $2.00 \mathrm{a}$ & $1.00 \mathrm{a}$ & $0.67 \mathrm{a}$ & $1.00 \mathrm{a}$ & $2.00 \mathrm{a}$ & $2.00 \mathrm{a}$ \\
P. foetida & $0.33 \mathrm{a}$ & $0.67 \mathrm{a}$ & $0.33 \mathrm{~b}$ & $1.00 \mathrm{a}$ & $1.33 \mathrm{a}$ & $1.33 \mathrm{a}$ & $0.67 \mathrm{~b}$ & $0.00 \mathrm{~b}$ \\
P. nítida & $0.00 \mathrm{a}$ & $0.33 \mathrm{a}$ & $0.00 \mathrm{~b}$ & $0.33 \mathrm{a}$ & $0.33 \mathrm{a}$ & $0.67 \mathrm{a}$ & $0.00 \mathrm{~b}$ & $0.00 \mathrm{~b}$ \\
P. quadrangularis & $0.33 \mathrm{a}$ & $0.00 \mathrm{a}$ & $1.33^{\mathrm{a}}$ & $0.67 \mathrm{a}$ & $0.00 \mathrm{a}$ & $0.00 \mathrm{a}$ & $0.67 \mathrm{~b}$ & $0.33 \mathrm{~b}$ \\
\hline
\end{tabular}

${ }^{1}$ Means followed by the same lowercase letters VERTICALLY constitute a statistically homogeneous group by Scott-Knott test at $5 \%$ probability level $(\mathrm{P}<0.05)$.

Table 6. Average of number of plants in which the lesion injured the plant marrow (NPLM), number of plants in which the lesion has reached less than $50 \%$ of the plant circumference (NPL-50\%) and area below the disease progress curve (AUDPC) of four genotypes of deferent species of passion fruit, inoculated with eight Fusarium solani.

\begin{tabular}{lccc}
\hline Genotypes of Passiflora spp. & NPLM & NPL-50\% & AUDPC \\
\hline P. edulis & $1.92 \mathrm{a}^{1}$ & $1.58 \mathrm{a}^{1}$ & $45.64 \mathrm{a}^{1}$ \\
P. foetida & $1.75 \mathrm{a}$ & $1.88 \mathrm{a}$ & $34.07 \mathrm{~b}$ \\
P. nitida & $1.29 \mathrm{~b}$ & $1.79 \mathrm{a}$ & $55.23 \mathrm{a}$ \\
P. quadrangularis & $1.63 \mathrm{a}$ & $1.46 \mathrm{~b}$ & $48.45 \mathrm{a}$ \\
\hline
\end{tabular}

${ }^{1}$ Means followed by the same lowercase letters constitute a statistically homogeneous group by Scott-Knott test at $5 \%$ probability level (P $\left.\leq 0.05\right)$.

Analyzing all the species tested in this manuscript, P. quadrangularis, P. foetida and P. nitida, were higher resistance to $F$. solani complex fungi when compared with $P$. edulis.. The highest resistance to the isolates of $F$. solani was observed in the species P. foetida and P. nitida. Preisigke et al. (2015b) also identified P. nitida as the most resistance specie to $F$. solani in their work. Also these authors determined that the period from inoculation until the lesion reaches more than $50 \%$ of the circumference of the injured stem and the area under the curve of expansion of the width of the injury as most effective resistance traits to discriminated the resistant and susceptible genotypes.
By that analyzing our data, P. quadrangularis and $P$. edulis were considered susceptible when compared with P. nitida and P. edulis. Contradictory results were obtained by other author, where they considered genotypes of $P$. quadrangularis at the same level of resistance to $F$. solani complex when compared to $P$. nitida and $P$. foetida (FISCHER et al., 2010; PREISIGKE et al., 2015a) 
The specie P. quadrangularis was highly susceptible to the pathogen for the three characteristics evaluated, NPLM, NPL-50\% and AUDPC. The susceptibility reported in the present study differs from that reported by Preisigke et al.(2015b). These results emphasize the existence of genetic variability within the species. The highest resistance to the isolates of $F$. solani was observed in the species $P$. foetida and P. nitida.

As for the significant difference observed for the F. solani isolates FS8A and FS3P in relation to the other isolates, there is a higher aggressiveness of these isolates, being thus observed the existence of genetic variability among isolates from different biomes. The genetic variability found in the present work is explained by Dariva et al. (2015), where the genetic variability among populations of $F$. solani may be associated with the sexual phase of the fungus, which allows the crossing of different individuals, thus increasing genetic variability.

Genetic resistance of Passiflora species to different isolates of $F$. oxysporum f. sp. Passiflorae complex

The results of variance analysisshown significative $(p \leq 0,05)$ differences between Passiflora species to the reaction to the F. oxysporum f. sp. Passiflorae complex, by the resistance traits, mean survival time (MST) in days after inoculation (DAI) and number of live plants (NLP). Also three different isolates of F. oxysporum $\mathrm{f}$. sp. passiflorae were inoculated in the five different species of Passiflora spp. and significant differences between the isolates were not identified. Also the interactions between the different species of Passiflora and the three isolates were not significant $(p \leq 0,05)$.

Table 7 present the Scott-Knott grouped test $(\alpha \leq 0,05)$ of the resistance traits MST and NLP, in five different Passiflora species, evaluated for susceptibility/ resistance to F. oxysporum f. sp. passiflorae complex. The species $P$. mucronata, P. nitida and P. morifolia survived longer (mean of 36.3 days), when compered with species $P$. edulis Sims and P. foetida (mean of 28.5 days after inoculation), demonstrating their greater susceptibility.

When the species were compared between them by the average number of live plants, three groups were formed. The group with the highest number of survival, was formed by the species P. mucronata (mean of 1.5 plants) and $P$. nitida (mean of 1.2 plants). The intermediate group was formed by the species P. foetida and P. morifolia, while $P$. edulis Sims showed the lowest average number of live plants after inoculation, highlighting the susceptibility of this specie to $F$. oxysporum f. sp. passiflorae complex pathogen (Table 7).

Table 7. Average Mean Survival Time (MST) and Number of Live Plants (NLP) of the five passion fruit genotypes inoculated with three isolates of Fusarium oxysporum f. sp. passiflorae.

\begin{tabular}{lcc}
\hline \multirow{2}{*}{ Genotypes of Passiflora spp. } & \multicolumn{2}{c}{ Characteristics } \\
\cline { 2 - 3 } & MST (DAI) & NLP \\
\hline P. edulis & $28.1 \mathrm{~b}^{1}$ & $0.2 \mathrm{c}$ \\
P. mucronata & $38.0 \mathrm{a}$ & $1.5 \mathrm{a}$ \\
P. nitida & $37.2 \mathrm{a}$ & $1.2 \mathrm{a}$ \\
P. foetida & $28.9 \mathrm{~b}$ & $0.6 \mathrm{~b}$ \\
P. morifolia & $33.8 \mathrm{a}$ & $0.9 \mathrm{~b}$ \\
\hline
\end{tabular}

${ }^{1}$ Means of genotypes followed by the same letter in the column do not differ statistically from each other by Scott-Knott test at $5 \%$ probability level.

In general, the species P. mucronata and P. nitida ecause were always in the groups of higher averages for the two characteristics realated to resistance, showing to be the most resistant to F. oxysporum f. sp. Passiflorae, (Table 7) in comparison with another genotypes assessed. In turn, the genotype $P$. edulis Sims was shown to be the most susceptible, being always allocated in the groups of smaller averages for the two characteristics, MST and NLP.
P. nitida and P. mucronata were the most resistant to $F$. oxysporum f. sp. passiflorae. Similar results are demonstrated by (Preisigke et al., 2015a), in which $P$. nitida and $P$. mucronata were resistant to the fungus, together with $P$. foetida and $P$. morifolia. In the present study, P. foetida was susceptible to the pathogen. 
Silva et al. (2013) evaluated the behavior of 31 accessions of Passiflora regarding the premature death of plants caused by F. oxysporum f. sp. passiflorae, of which 24 accessions were $P$. edulis Sims (purple and yellow) and hybrid $P$. edulis Sims, which were susceptible to $F$. oxysporum $\mathrm{f}$. sp. passiflorae. The susceptibility of $P$. edulis Sims to F. oxysporum f. sp. passiflorae is also reported in this work and in the work by (PREISIGKE et al., 2015a).

There was no significant difference between the isolates of $F$. oxysporum f. sp. passiflorae, with no pathogenic variability among the isolates under study. This is indicate that only one isolate of $F$. oxysporum f. sp. Passiflorae can be used for resistant selection in the interspecific breeding program aiming resistance of passion fruit against F. oxysporum f. sp. Passiflorae. Contraditory results were found by Melo et al. (2020), were variability were observed among the isolates of Fusarium oxysporum f.sp. passiflorae.

\section{Conclusions}

According to the results presented in this study, the genotype from $P$. foetida specie is indicated as the most resistant against $F$. solani and $P$. mucronata is indicated as the most resistant to $F$. oxysporum f. sp. Passiflorae. $P$. nitida can be indicated as resistant to both $F$. solani and $F$. oxysporum f. sp. passiflorae. These gentypes fromdiferent species are possible recurrent genotypes for passion fruit genetic breeding programs.

\section{Acknowledgements}

To CAPES/FAPEMAT for the financial support of the research, to the PGMP and to the research team of the Laboratory of Genetics and Plant Breeding of UNEMAT.

\section{References}

BERNACCI, L.C.; CERVI, A.C.; MILWARDDEAZEVEDO, M.A.; NUNES, T.S.; IMIG, D.C.; MEZZONATO, A.C. Passifloraceae in Lista de Espécies da Flora do Brasil. Jardim Botânico do Rio de Janeiro, 2015. Disponível em: http://floradobrasil.jbrj.gov.br/jabot/ floradobrasil. Acesso em: 02/10/2019

BERNACCI, L.C.; CERVI, A.C.; MILWARD-DEAZEVEDO, M.A.; NUNES, T.S.; IMIG, D.C.; MEZZONATO,A.C. Passifloraceae $I n$ : LISTA de espécies da Flora do Brasil. Rio de Janeiro: Jardim Botânico, 2014. Disponível em: http://floradobrasil.jbrj.gov.br/jabot/ floradobrasil. Acesso em: 02 out. 2019.
CLARK, R.B. Characterization of phosphates in intact maize roots. Journal of Agriculture and Food Chemistry, Washington, v.23, p.458-460, 1975.

CRUZ, C.D. GENES: a software package for analysis in experimental statistics and quantitative genetics. Acta Scientiarum Agronomy, Maringá, v.35, n.3, 271-276, 2013.

DARIVA, J.M.; XAVIER, A.A.; COSTA, M.R.; RIBEIRO, R.C.F.; SOUSA, T.v.Variabilidade genética de isolados de Fusarium solani e fusarium oxysporum f. Sp. Passiflorae Associados ao maracujazeiro. Revista Brasileira de Fruticultura, Jaboticabal, v.37, n.2, p.377-386, 2015.

FISCHER, I.H.; MARTINS, M.C.; LOURENÇO, S.A.; KIMATI, H.; AMORIM, L. Reação de espécies de Passiflora à Podridão do colo, causada por Fusarium solani e Phytophthora nicotianae. Fitopatologia Brasileira, Brasília, DF, v.21, p.28-271, 2003.

FISCHER, I.H.; ALMEIDA, A.M.; FILETI, M.S.; BERTANI, R.M.A.; ARRUDA, M.C.; BUENO, C.J. Avaliação de Passifloraceas, fungicidas e Trichoderma para o manejo da Podridão-docolo do maracujazeiro, causada por Nectria haematococca. Revista Brasileira de Fruticultura, Jaboticabal, v.32, p.709-717, 2010.

FLORES, P.S.; OTONI, W.C.; DHINGRA, O.D.; DINIZ, S.P.S.S.; SANTOS, T.M.; BRUCKNER, C.H. In vitro selection of yellow passion fruit genotypes for resistance to Fusarium vascular wilt. Plant Cell Tissue and Organ Culture, Dordrecht, v.108, n.1, p.37-45, 2012.

FRY, W.E. Integrated control of potatoes late blight: effects of polygenic resistance and techniques of timing fungicide application. Phytopathology, Saint Paul, v.67, p.15-420, 1977.

IBGE 2017. Produção Agrícola Municipal. Disponível em ftp://ftp.ibge.gov.br/Producao_Agricola/Producao Agricola_Municipal_[anual]/2017/pam2017.pdf. Accessed in 04 February 2019

MAROSTEGA, T.N.; LARA, L.P.; OLIVEIRA, D.S.; CHIMELLO, A.M.; GILIO, T.A.S.; PREISIGKE, S.C.; ARAUJO, K.L.; SERAFIM, M.E.; NEVES, L.G. Molecular and aggressiveness characterization of isolates of Fusarium solani and Fusarium oxysporum f.sp. passiflorae associated to passion fruit wilting. Journal of Agricultural Science, Cambridge, v.11, n.3, p.407420, 2019. 
MELO, N.J.A.; NEGREIROS, A.M.P.; MEDEIROS, H.L.S.; SALES JÚNIOR, R. Evaluation of Fusarium wilt disease in passion fruit species inoculated with Fusarium oxysporum f.sp.passiflorae. Journal of Phytopathology, Berlin, v.168, p.81-87, 2020.

MUNHOZ, C..F.; COSTA, Z.P.; CAUZ-SANTOS, L.A.; CAUZ-SANTOS, L.A.; REÁTEGUI, A.C.E.; RODDE, N.; CAUET, S. DORNELAS, M.C.; LEROY, P.; VARANI, A.M.; BERGES, H.; VIEIRA, M.L.C. A gene-rich fraction analysis of the Passiflora edulis genome reveals highly conserved microsyntenic regions with two related Malpighiales species. Scientific Reports, London, v.8, n.13024, 2018.

PREISIGKE, S.C.; MARTINI, F.V.; ROSSI, A.A.B.; SERAFIM, M.E.; BARELLI, M.A.A.; LUZ, P.B.; ARAÚJO, K.L.; NEVES, L.G Genetic variability of Passiflora spp.against collar rot disease. Australian Journal of Crop Science, Melbourne, v.9, p.69-74, 2015 a.

PREISIGKE, S.C.; NEVES, L.G.; ARAÚJO, K.L.; BARBOSA, N.R.; SERAFIM, M.E.; KRAUSE, W. Multivariate analysis for the detection of Passiflora species resistant to colar rot. Bioscience Journal, Uberlândia, v.31, p.1700-1707, 2015b.
SANTOS, C.H.B.; OLIVEIRA, E.J.; LARANJEIRA, F.F.; JESUS, O.N.; GIRARDI, E.A. Growth, fruit set, and fusariosis reaction of yellow passion fruit grafted onto Passiflora spp. Revista Brasileira de Fruticultura, Jaboticabal, v.38, n.3, p.e-711, 2016.

SHANER, G.; FINNEY, R.E. The effect of nitrogen fertilization on the expression of slow-mildewing resistence in: knox wheat. Phytopathology, Saint Paul, v.67, p.1051-1056, 1977.

SILVA,A.S.; OLIVEIRA, E.J.;HADDAD, F.; LARANJEIRA, F.F.; JESUS, O.N.;OLIVEIRA, S.A.S .; COSTA, M.A.P.C.; FREITAS, P.X. Identification of passion fruit genotypes resistant to Fusarium oxysporum f. sp.passiflorae. Tropical Plant Pathology, Brasília, v.38, p.236-242, 2013.

SILVA R.M.; AMBRÓSIO M.M.Q.; AGUIAR A.V.M.; FALEIRO F.G.; CARDOSO M.A.S.; MENDONÇA V. Reação de cultivares de maracujazeiro em áreas com fusariose. Summa Phytopathol, v.43, p.98-102, 2017.

VANDERPLANK, J. Passiflora quadrifaria Passifloraceae. Curtis's Botanical Magazine, Edinburgh, v.13, p.63-69, 1996. 